\title{
MEME POLITIK DI MATA PEMILIH MUDA SUMBAWA
}

\author{
Miftahul Arzak \\ Dosen Program Studi Ilmu Komunikasi, Fakultas Ilmu Komunikasi Universitas Teknologi Sumbawa \\ miftahularzak@yahoo.com
}

\begin{abstract}
ABSTRAK
Penelitian ini bertujuan untuk mengetahui penerimaan pemilih muda terhadap kampanye politik menggunakan Meme. Meme dalam kampanye politik praktis tergolong dalam kampanye kreatif dan baru di Indonesia, khususnya di Sumbawa. Terlebih disebarkan melalui media sosial. Dalam penelitian ini, peneliti akan menggunakan metode analisis resepsi (reception analysis) milik Stuart Hall untuk melihat bagaimana penerimaan dan tanggapan pemilih muda di Sumbawa terhadap Meme sebagai Media Kampanye Politik Pemilihan Bupati dan Wakil Bupati Kabupaten Sumbawa Periode 2016-2021 di media sosial. Pertama, Peneliti akan mencari Preferred Reading dari Meme sebagai salah satu media kampanye dengan melakukan encoding-decoding. Dari Preferred Reading tersebut, peneliti akan mendapatkan wacana yang hadir di dalam Meme serta menjadi acuan pertanyaan ke informan. Kedua, Peneliti akan mewawancarai narasumber yang merupakan Pemilih Muda di Kabupaten Sumbawa, antara lain 4 sampel dari pelajar Sekolah Menengah Atas dan Mahasiswa yang berumur 17-19 tahun atau yang baru pertama kali ikut berpartisipasi pada pemilihan umum di Sumbawa. Persebaran sampel berada pada Kabupaten Sumbawa bagian Barat, di Kabupaten Sumbawa bagian Timur, di Kabupaten Sumbawa bagian Selatan dan di Kota Sumbawa. Dari penelitian tersebut akan didapatkan penerimaan informan terhadap meme sebagai media kampanye politik pada Pemilihan Bupati Sumbawa Periode 2016-2021.
\end{abstract}

Kata Kunci: Analisis Resepsi, Kampanye Politik, Meme, Pemilih Muda

\section{PENDAHULUAN}

Pemberitaan tentang pertarungan politik untuk merebut kursi orang nomor satu di setiap daerah semakin gencar setelah memasuki akhir tahun 2015. Berbagai strategi periklanan untuk memperkenalkan caloncalonnya pun beraneka ragam. Dari cara konvensional seperti memasang poster di tembok-tembok, spanduk serta baliho. Memasang iklan di media cetak, radio maupun televisi lokal, hingga mulai menyentuh ke media baru salah satunya memanfaatkan media sosial (medsos).

$$
\text { Euphoria pemilu dengan }
$$

memanfaatkan media sebagai alat kampanye politik juga dirasakan oleh salah satu kabupaten di Provinsi Nusa Tenggara Barat, yaitu Kabupaten Sumbawa. Sebagai salah satu kabupaten yang melaksanakan pemilu serentak di tahun 2015 lalu, Kabupaten Sumbawa memiliki 3 (tiga) pasang calon bersamaan dengan jargon yang mereka perkenalkan di masyarakat.

Pada nomor urut 1 ada pasangan Jack Morsa, S. Adm berpasangan dengan Iwan Rahadi, ST dengan jargonnya JIWA (JACKIWAN) yang didukung oleh Partai Gerakan Indonesia Raya (Gerindra) dan Partai Keadilan Sejahtera (PKS).
Nomor urut 2 ada pasangan Asaat Abdullah, ST berpasangan dengan Chandra Wijaya Rayes, ST dengan jargonnya SAATnya Sumbawa BerJAYA yang didukung oleh Partai Hati Nurani Rakyat (Hanura), Partai Nasional Demokrat (NasDem) serta Partai Keadilan dan Persatuan Indonesia (PKPI).

Nomor urut 3 yang juga pasangan pemenang dalam pemilu tersebut yaitu Muhammad Husni Djibril, B.Sc berpasangan dengan Drs. H. Mahmud Abdullah dengan jargonnya HUSNI-MO yang didukung oleh Partai Demokrasi Indonesia Perjuangan (PDI P) dan Partai Demokrat (dalam Julmansyah dan Arzak, 2017: 69).

Dalam proses kampanye politik, ketiga calon Bupati dan Wakil Bupati Sumbawa ini memanfaatkan beragam media, seperti radio, koran, spanduk dan baliho. Namun di dalam penyebaran kampanye politik, para calon, simpatisan serta tim sukses juga banyak menggunakan medsos seperti facebook, twitter, instagram, path dan medsos lainnya untuk memperkenalkan calonnya. Pemilihan penggunaan medsos sebagai salah satu media kampanye politik oleh para calon, simpatisan serta tim sukses dikarenakan masyarakat di 
belahan dunia saat ini sedang merasakan euphoria penggunaan medsos. Sedangkan media kampanye yang digunakan beraneka ragam, salah satunya adalah meme.

Meme atau sering disebut sebagai meme culture merupakan salah satu fenomena baru dalam dunia komunikasi di Indonesia yang telah merambah ke dunia politik. Meme merupakan imitasi dan transmisi budaya lewat interaksi pembicaraan orang melalui medium analog maupun digital (Brunello, 2012: 21). Di dalam praktik berpolitik di Indonesia masa kini, meme sering digunakan untuk menampilkan kombinasi antar gambar foto, slide dan teks serta ditujukan untuk merespon suatu isu yang sedang diperbincangkan (Wadipalapa, 2015: 1-18)

Inilah salah satu pilihan tim sukses, simpatisan dan calon pemimpin di beberapa daerah di Indonesia menggunakan media sosial sebagai salah satu media kampanye politik, terlebih penggunaan meme adalah untuk mensasar pemilih muda. Pemilih muda memiliki peran penting dalam pemilu di Indonesia maupun daerah, karena sebanyak $20 \%$ dari seluruh pemilih adalah pemilih muda. Dengan demikian jumlah pemilih muda sangatlah besar sehingga para calon sangat membutuhkan suara-suara dari pemilih pemula untuk kemenangannya (KPU, 2010: 48).

Pemilih muda merupakan masyarakat di suatu daerah yang baru saja mendapat kesempatan untuk menggunakan hak suaranya untuk melakukan pemilihan umum. Seperti seorang yang baru berumur 17 tahun, Oleh karena itu, pendekatan politik yang digunakan untuk mereka salah satunya dengan pendekatan kreatif melalui medsos.

Pemilihan medsos sebagai media kampanye, dikarenakan anak muda gemar dan lebih dekat dengan media online. Seperti penjelasan Jesse Drew (2013:8) yang menyebutkan bahwa anak muda lebih terampil atau familiar dibandingkan usia-usia di atas maupun di bawahnya dalam memanfaatkan teknologi. Alasannya karena kegiatankegiatan yang mereka lakukan lebih dekat dengan teknologi-teknologi yang sedang berkembang, seperti membuka web, mencari dan men-share musik, mencari literatur serta menemukan generasi-generasi sejenis dalam memanfaatkan media online. Walaupun tidak dipungkiri sebagian kecil generasi di bawah maupun di atasnya juga ada yang mengkonsumsi media sosial. Selain itu, hadirnya pemilih muda ini juga kadangkala mempengaruhi hasil pemilu, walaupun tidak jarang mereka jarang diperhatikan oleh calon legislatif, maupun eksekutif.

Seperti penelitian yang dilakukan oleh Imam Maliki dan Riri Satria, berjudul "Pengaruh Kampanye Politik di Media Sosial terhadap Opini yang Terbentuk: Studi Kasus Pilkada DKI Jakarta 2012". Penelitian yang mereka lakukan bertujuan untuk mengetahui apakah kampanye politik di media sosial berpengaruh terhadap opini yang terbentuk pada PILKADA DKI Jakarta tahun 2012. Data diambil dari pengguna media sosial dengan proses sampling sebanyak 278 pengguna. Perkiraan tingkat kesalahan pengambilan sample sebesar 6\%. Teknik pengolahan data menggunakan SPSS 17 sebagai alat bantu mengolah data. Pada akhir penelitiannya, Maliki dan Satri berpendapat bahwa media sosial menjadi alat bagi netizen sebagai pemrediksi kemenangan. Dimana kebebasan berpendapat, melakukan kampanye hitam, kampanye bersih dan negatif juga berlangsung.

Selain itu, pasangan Cagub dan Cawagub yang diteliti oleh mereka berasumsi bahwa melakukan kampanye di media sosial dapat menggiring opini para pengguna media sosial tersebut. Salah satu penggunanya adalah anak muda yang di dalam pengalamannya, baru mengenal dunia politik. Inilah yang meragamkan hasil pemilihan.

Penelitian selanjutnya yang menjadi acuan peneliti berjudul "Meme Culture dan Komedia-Satire Politik: Kontestasi Pemilihan Presiden dalam Media Baru" oleh Rendy Pahrun Wadipalapa yang lebih spesifik membahas tentang internet yang di dalamnya ada meme culture hadir di tengah kontestansi politik di Indonesia. Wadipalapa sepakat bahwa internet penting dalam mendorong demokrasi di Indonesia, terlebih setelah Indonesia terlepas dari masa orde baru. Kebebasan berpendapat, memberikan komentar dan menampilkan ekspresi menjadi serba terbuka, terlebih internet memfasilitasi perubahan-perubahan tersebut. Salah satunya dengan kehadiran meme culture seperti yang dijelaskan dalam tulisan Wadipalapa. Mengutip pernyataan Brunello (2012), Wadipalapa menyadari bahwa meme merupakan gejala yang sangat baru dalam konteks media di Indonesia. Dengan mengutip 
beberapa akun twitter dan facebook tempat penyebaran meme, Wadipalapa menemukan bahwa media sosial yang di dalamnya dihadirkan media kreatif dalam kampanye seperti meme bukanlah teks yang diam atau pasif, melainkan menjawab dan menggambarkan peristiwa yang ada di masyarakat. Selain itu, meme juga dilihat sebagai gerakan politik, walaupun dalam wilayah virtual.

Meme juga dapat menjadi respon alternatif dari semua saluran kritik dan protes atas elite politik oleh netizen. Apatisme politik seringkali tidak diimbangi dengan partisipasi dan pemaparan sikap publik. Meme memperjelas sikap itu, kebuntuan respon misalkan melalui demonstrasi kemudian berubah menjadi sebuah meme dan dihadirkan di tengah-tengah masyarakat dunia maya.

Dari berbagai media kampanye yang hadir di dalam pemilihan bupati dan wakil bupati Kabupaten Sumbawa periode 20162021 ini, penulis bermaksud untuk mengetahui penerimaan pemilih muda serta yang mempengaruhi penerimaan pemilih muda tersebut terhadap meme sebagai Media Kampanye Politik Pemilihan Bupati dan Wakil Bupati Kabupaten Sumbawa Periode 2016-2021 melalui media sosial.

\section{METODOLOGI}

Dalam penelitian ini yang menjadi informan penelitian adalah Pemilih Muda di Pemilihan Umum Bupati dan Wakil Bupati Kabupaten Sumbawa tahun 2015. Yaitu anak muda Sumbawa yang baru melaksanakan pemilihan umum, antara lain: Anak Sekolah Menengah Atas persebaran di Sumbawa bagian Barat, Sumbawa Besar, Sumbawa bagian Selatan serta Sumbawa bagian Timur, tentunya yang menggunakan dan melakukan aktivitas sehari-hari dengan memanfaatkan media sosial.

Dalam melihat penerimaan informan terhadap meme sebagai media kampanye politik di media sosial, tahapan yang dilakukan peneliti untuk mengumpulkan data tersebut, yaitu melalui Wawancara. Wawancara merupakan alat pengumpulan data yang sangat penting dalam penelitian kualitatif yang melibatkan manusia sebagai subjek (pelaku, aktor). Dalam penelitian komunikasi kualitatif dikenal salah satu wawancara, yaitu wawancara informal (Pawito, 2007:132).
Dalam penelitian yang berhubungan dengan analisis resepsi Pemilih Muda dalam merespon "Meme" sebagai Media Kampanye Politik ini, peneliti akan melihat dari berbagai sudut pandang. Data-data yang didapatkan bukan hanya dari sisi informan saja, melainkan dari sisi tampilan meme di media sosial.

Pertama, peneliti mencoba melihat makna-makna yang diproduksi oleh meme melalui encoding. Menjelaskan tentang encoding, menurut Hall (1981) mengartikan proses encoding televisi sebagai suatu artikulasi momen-momen produksi, sirkulasi, distribusi dan reproduksi yang saling terhubung dalam tayangan media (Barker, 2011:287). Oleh karena itu, dalam penelitian ini melihat bahwa sebenarnya media, khususnya media sosial dalam penelitian ini mencoba menyampaikan atau memproduksi makna yang akan disampaikan kepada netizen berhubungan dengan kampanye politik pemilihan Bupati dan Wakil Bupati Kabupaten Sumbawa periode 2016-2021.

Peneliti mencoba melihat proses produksi, alur jalannya berita dan distribusi yang berhubungan dengan waktu dan isi dalam meme tersebut. Seperti penjelasan John Storey (2008) dalam buku Cultural Studies dan Kajian Budaya Pop. Momen produksi media dibingkai seluruhnya oleh maknamakna dan ide-ide, praktik pengetahuan yang menyangkut "rutinitas" produksi. Oleh karena itu peneliti dalam melihat tampilan meme tersebut, juga melihat rutinitas kehadiran meme di dalam media sosial. Dibalik itu, untuk menambah beberapa penggalian data, peneliti mencoba menganalisis data dengan bantuan framing, penggunaan analisis framing oleh peneliti hanya dibatasi untuk mencari data-data menunjukkan kecenderungan makna yang dihadirkan oleh meme tersebut. Beberapa langkah framing yang akan dilakukan antara lain (Eriyanto, 2009:70):

Pertama, melalui fakta realitas. Dalam analisis ini, peneliti melihat tampilan meme melalui asumsi atau teks secara tertulis dari. Kedua dengan menuliskan fakta, proses dimana berhubungan dengan fakta yang disajikan kepada netizen. Menuliskan fakta dengan melihat perangkat tertentu, penempatan yang mencolok seperti tulisan dan gambar hingga melihat tampilan caloncalon Bupati dan Wakil Bupati tersebut. Ini 
semua dilakukan oleh peneliti sebagai bahan dasar awal atau penuntun peneliti untuk menyiapkan pertanyaan dan sebagai batasan-batasan peneliti dalam melakukan langkah penelitian terhadap informan. Setelah itu, peneliti mencoba melihat penerimaan informan terhadap meme dalam kampanye politik. Dalam proses decoding, Counihan menjelaskan bahwa decoding merupakan proses menafsirkan tanda-tanda oleh informan. Informan secara aktif terlibat masuk dalam tampilan di media sosial yang sama diterjemahkan oleh orang-orang dari latar belakang sosial dan budaya yang berbeda (Moorley, 1992:72).

Melalui bahan-bahan data encoding dan decoding tersebut, peneliti melakukan analisis data dengan mencoba melihat penerimaan informan yang didapat dari wawancara, data kemudian dikelompokkan sehingga terkumpul dan menjadi sebuah tulisan serta diolah atau menjadi sebuah tulisan yang mudah dimengerti.

\section{PEMBAHASAN \\ Meme sebagai Wajah Pada Media Kampanye Politik}

1. Nomort urut: Daya Tarik Kampanye

Pembagian nomor urut menjadi salah satu momen yang ditunggu-tunggu oleh pasangan calon. Selain untuk menunjukkan nomor peserta di dalam pertarungan politik antar daerah, nomor urut juga dapat dikaitkankaitkan dengan jargon dan materi kampanye politik para calon. Ada banyak jargon-jargon yang hadir di saat pemilukada berlangsung. Diantaranya Jargon yang dikaitkan dengan nomor urut yang dihubungkan dengan isu nasional, daerah, bahasa asing hingga bahasa daerah. Bahkan fenomena menghubunghubungkan isu dengan tampilan meme kadang tidak juga relevan. Namun, kehadiran meme politik tersebut tidak hanya sedang berbicara tentang isu politik saja, melainkan ada unsur humor, unik dan kreativitas dari segi tampilannya. Seperti pada salah satu meme pasangan calon nomor urut 1 :

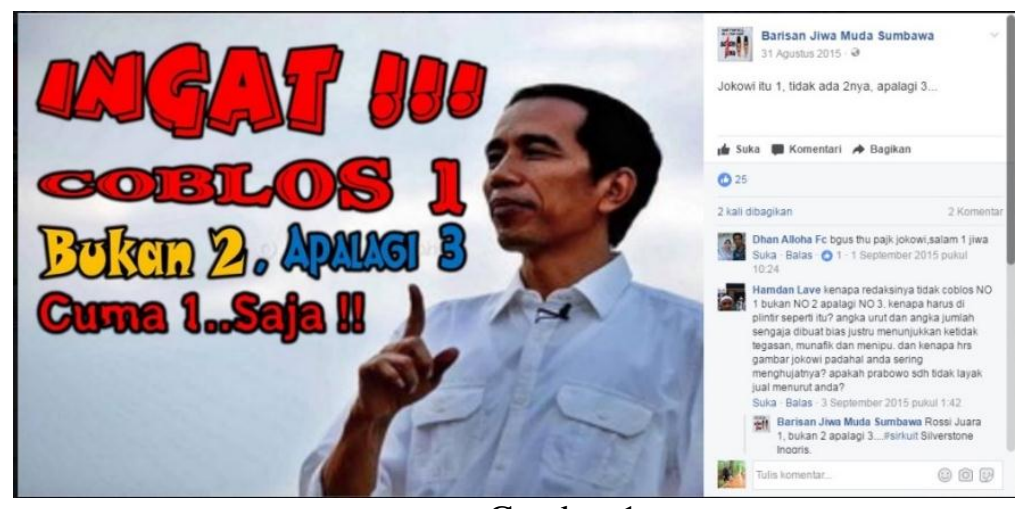

Gambar 1

(Salah satu Meme Pasangan Nomor urut 1, JIWA)

Gambar di atas merupakan salah satu meme pasangan calon Bupati dan Wakil Bupati nomor urut 1 ini (Jack-Iwan). Pada meme yang diunggah oleh salah satu tim pemenang JackIwan pada 31 Agustus 2015 ini, pengunggah memberikan caption "Jokowi itu satu, tidak ada 2nya, apalagi 3" dengan gambar Jokowi serta tulisan di gambar "INGAT!!! Coblos 1, Bukan 2. Apalagi 3. Cuma 1...Saja!!.

Nomor urut 1 menjadi salah satu nomor yang diidam-idamkan oleh pasangan calon dalam pemilihan eksekutif maupun legialatif. Selain menjadi nomor yang paling awal, nomor satu juga sering dikaitkan-kaitkan dengan yang pertama atau yang utama untuk dipilih, seperti kalimat bahwa "Allah SWT itu Esa", maka dapat dimaknai bahwa Allah SWT adalah satusatunya Tuhan yang diimani bagi umat Muslim. Hadirnya Jokowi di dalam gambar tersebut juga ingin menunjukkan hadirnya sosok nomor satu di Indonesia atau sosok Presiden. Keterkaitan nomor urut 1 dengan presiden menjadi daya tarik tersendiri untuk netizen. Inilah yang ditonjolkan oleh komunikator pada komunikan di dalam meme tersebut.

Selain itu, pada warna tulisan meme juga ditunjukkan sebagai sesuatu yang spesial. INGAT!!! Coblos 1 (warna merah), Bukan 2 (kuning), Apalagi 3 (biru). Cuma 1...Saja!! (merah) menunjukkan ada 3 kelompok warna yang dihadirkan oleh tim pembuatan meme. 
Merah, Kuning dan Biru. tidak ada pemaknaan khusus pada warna tersebut, namun warna merah dengan kombinasi terbanyak pada tulisan menunjukkan warna merah menjadi sesuatu yang ditonjolkan atau dominan.

Merah memang sering dihubungkan dengan berani, kekuatan, tekad yang kuat serta memiliki emosional yang kuat (Susanto, 2007:231). Pada Kata "INGAT!!! Coblos 1 dan Cuma 1...Saja!!" ingin menekankan pada pilihan yang harus diingat hanya nomor 1 dan hanya 1 saja. Pengulangan kata di dalam baris kampanye politik tersebut menunjukkan sesuatu penekanan agar selalu diingat, sedangkan warna yang lainnya hanya menjadi figuran warna saja, sehingga di dalam meme tersebut ada makna penekanan nomor urut sebagai salah satu daya tarik pada pemilih. Selain pasangan JIWA, penulis juga menganalsis meme yang dihadirkan oleh kandidat nomor urut 3, Husni-Mo yang menonjolkan nomor urut melalui bahasa daerah Sumbawa.

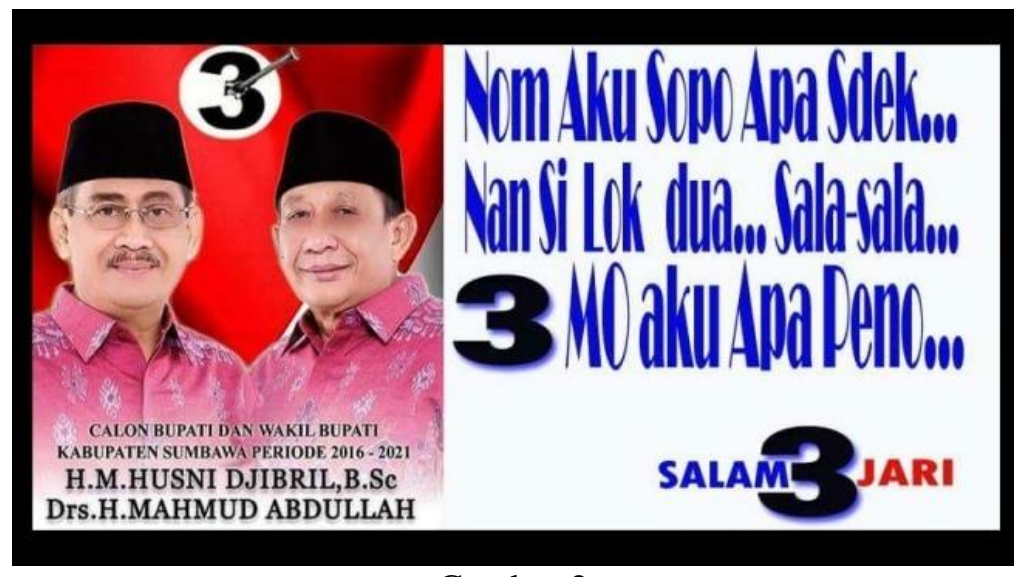

Gambar 2

(Salah satu Meme Pasangan Nomor urut 3, Husni-Mo)

Bahasa daerah menjadi salah satu daya tarik bagi kampanye politik. Pada gambar di atas menunjukkan meme kampanye politik milik tim nomor urut 3 yaitu Husni-Mo. di samping meme tersebut bertuliskan: "Nom aku sopo apa sdek, nan si lok dua sala-sala, 3 mo aku apa peno". Artinya dalam bahasa Indonesia: "Aku tidak mau satu soalnya sedikit, begitu juga dua, tanggung. Aku pilih tiga saja yang banyak".

Melalui caption di sampingnya, pembuat meme ingin mempersuasi netizen untuk memilih nomor yang lebih banyak dibandingkan nomor yang lebih sedikit. Kalimat lebih banyak sebenarnya bisa dilihat melalui dua pemaknaan, negatif atau positif. Namun, pada kalimat di meme tersebut tidak sedang membandingkan dua pemaknaan tersebut melainkan menggunakan kalimatkalimat di dalam meme sebagai bentuk candaan. Candaan a'la masyarakat Sumbawa juga dikenal dengan istilah bagesa (bergaya), candaan yang sombong.

Bergaya atau "sombong" tidak selalu dimaknai sebagai sebuah sesuatu yang negatif di dalam kehidupan masyarakat Sumbawa. Di dalam sambutan Wakil Bupati terpilih, Drs. H.
Mahmud Abdullah (Mo), beliau pernah membuka acara hiburan di Sumbawa. Dengan tema "Samawa Maras Bagesa (SAMARASA)". Pak Mo berharap agar tau Samawa (orang Sumbawa) dikenal dengan istilah bagesa Samawanya sebagai bentuk gaya dan karektaristik orang Sumbawa. Acara "SAMARASA" ini merupakan stand up comedy a'la masyarakat Sumbawa. Dengan kata lain bagesa dapat menjadi salah satu hiburan yang berhubungan dengan karakteristik masyarakat Sumbawa itu sendiri.

Strategi ini cukup unik karena ingin menjelaskan bahwa nomor satu dan dua itu sedikit, sedangkan nomor 3 yang banyak. Dalam konteks "kepemilikan", jumlah yang banyak merupakan salah satu yang diinginkan oleh seseorang. Oleh karena itu, kata-kata "3 mo aku apa peno" menunjukkan bahwa tim kemenangan nomor urut 3 memiliki sesuatu yang lebih banyak dibandingkan nomor urut yang lain. Lebih banyak dapat diartikan sebagai kepemilikan kemampuan, lebih banyak memiliki peluang menjadi Bupati dan Wakil Bupati, lebih banyak pemilih dan pendukung sehingga yang belum mendukung mereka atau 
mendukung pasangan yang lain dapat merapat ke Hunsi-Mo.

Selain itu, jika membahas tentang penggunaan bahasa daerah di media kampanye, bahasa daerah merupakan salah satu daya tarik pada media kampanye. Kedekatan antar pemilih dengan calonnya dapat ditunjukkan dengan bahasa-bahasa pada media kampanye. Kampanye tentang kedaerahan atau asal pernah dilakukan oleh Presiden Obama. Asal dan ciri khas kulit dan wajahnya menjadikan daya tarik bagi pemilih (Kompas, 2009:185). Maka, tidak heran jika di dalam beberapa kampanye politik kadang menekankan kedaerahan dengan maksud untuk menunjukkan kedekatan antara pemilih dengan calon yang akan dipilih.
2. Tokoh: Daya Tarik bagi Pemilih

Tokoh di dalam perpolitikan Indonesia dapat menjadi magnet dan kekuatan di dalam basis penarikan pemilih. Kekuatan seseorang yang memiliki "ilmu" dan "passion" dibidangnya tersebut dapat menjadikan dirinya sebagai panutan bagi orang lain, yang akhirnya juga dapat mempengaruhi pemilih di dalam pemilukada. Terutama bagi tokoh-tokoh nasional yang mempengaruhi pemilih di tingkat daerah atau desa. Alasannya, tekanan dari masyarakat lebih mudah untuk dikoordinir melalui suara-suara mereka (tokoh) (Winarno, 2008:40). Seperti sosok-sosok tokoh nasional yang hadir di sebagian besar meme pada pemilihan Bupati dan Wakil Bupati di Kabupaten Sumbawa beberapa tahun lalu.

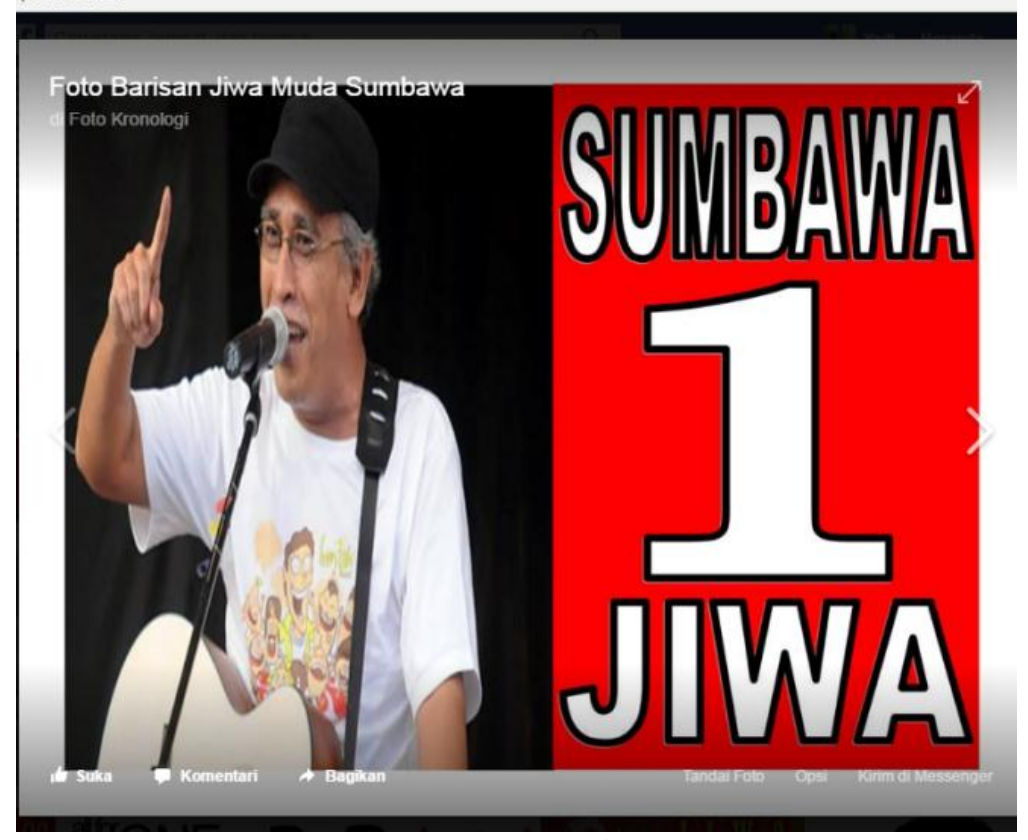

Gambar 3

(Iwan Fals sebagai salah satu tokoh di dalam meme kampanye politik)

Pada meme di atas dihadirkan sosok Iwan Fals atau tokoh sekaligus musisi Indonesia.

Sosok Iwan tidak hanya dikagumi oleh pecinta musik saja, melainkan oleh banyak lapisan masyarakat. Musik yang penuh dengan semangat kritikan-kritikan halus tentang perekonomian, politik serta sistem-sistem kenegaraan selalu dia tonjolkan di lirik lagunya. Iwan Fals pun pernah disebut-sebut sebagai salah satu calon presiden idaman di tengah masyarakat Indonesia pada Pemilihan Presiden tahun 2004 lalu.

Bahkan, di dalam buku Pahlawanpahlawan Belia: Keluarga Indonesia di Dalam Politik karya Saya S Shiraishi (2001:247-249) pernah melakukan penyebaran angket kepada anak muda di Indonesia untuk melihat tokoh-tokoh yang mereka kenal. Dari beberapa nama, Shiraishi menyebutkan Iwan Fals bahkan lebih "dikagumi" ketimbang Menteri Penerangan Harmoko saat itu. Selain itu, sosok musisi legendaris Indonesia ini pun dianggap tidak hanya berada dalam ruang lingkup seni saja, melainkan juga telah masuk dalam ruang lingkup perpolitikan di Indonesia.

Ketidaksadaran tim dalam pencatutan gambar di dalam materi media kampanye bukan sesuatu yang datang begitu saja. Subyek membagi nama-nama, momen, situasi, posisi 
yang dianggap "benar" dan pantas di sebutkan di dalam materi media kampanye, sehingga ada keputusan untuk menghadirkan sebuah pilihan. Pilihan-pilihan tersebut telah diseleksi dalam alam pikiran kita. Begitu pula dengan hadirnya musisi Indonesia seperti Iwan Fals.

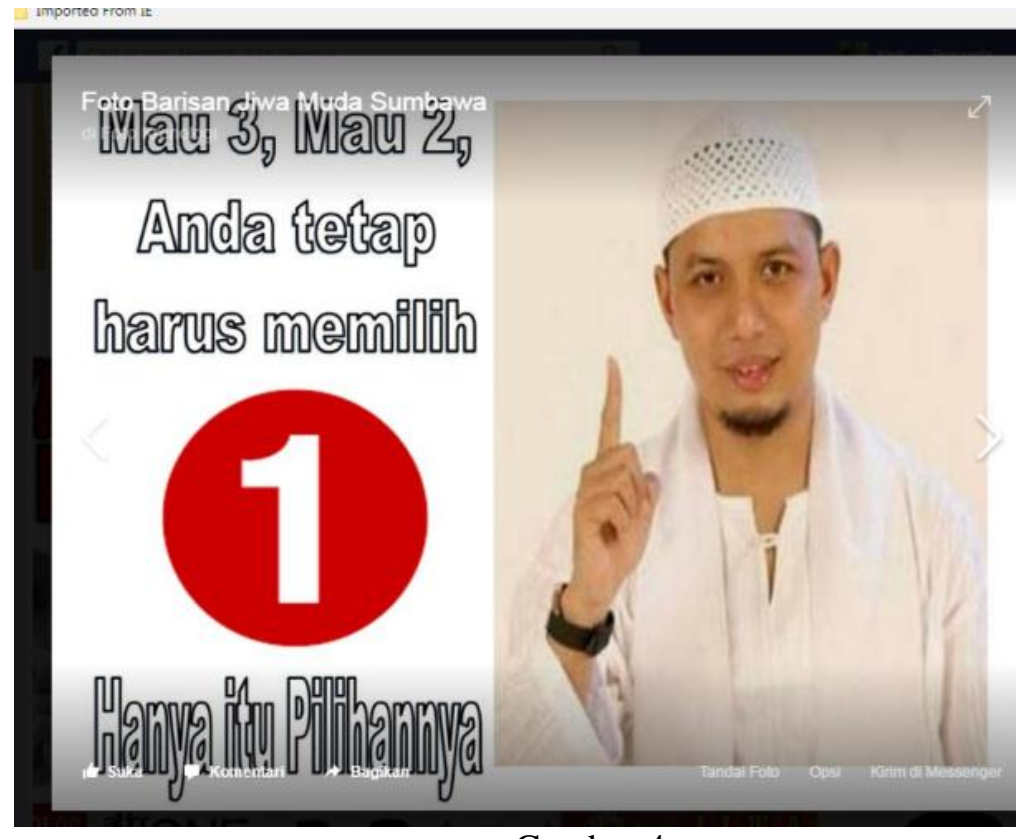

Gambar 4

(Salah satu Meme Pasangan Nomor urut 1, Jiwa)

Tidak hanya tokoh pada bidang permusikan Indonesia saja, Indonesia dengan kepadatan penduduk Muslimnya hingga disebut-sebut sebagai Negara terbanyak pemeluk agama Islam di dunia ini menjadikan tokoh agama Islam sebagai salah satu panutannya. Tidak hanya di ruang lingkup dakwah keagamaan saja, melainkan sosok panutan tersebut juga seringkali hadir di ruang lingkup perpolitikan Indonesia. Seperti sosok Ulama, Ustadz Muhammad Arifin Ilham yang dengan sengaja dihadirkan di meme salah satu calon pemilihan Bupati dan Wakil Bupati Kabupaten Sumbawa tahun 2015 lalu.

Hubungan kuat antara ulama kepada santrinya menjadi salah satu modal kuat pada perpolitikan, terutama untuk menarik massa (Pamungkas, 2017: 196). Para simpatisan atau di dalam ruang lingkup dakwah disebut sebagai santri menjadikan para pendakwah sebagai salah satu sosok panutannya. Sosok tersebut tidak akan bisa didapatkan dengan cara membeli menggunakan uang. Melainkan Sosok ulama tersebut didapatkan melalui perjalanan yang panjang, pergulatan keilmuan serta jam terbang yang tinggi di dalam berdakwah, sehingga ulama disematkan secara sengaja dengan penilaian yang panjang oleh masyarakat.
Setelah mengalami perjalanan yang panjang tersebut, tidak sedikit sosok santri kadang akan menutup mata untuk selalu membela kiainya dalam keadaan atau posisi apapun. Siapapun ulamanya, dia akan membela sekuat tenaga, harta bahkan tidak sedikit yang mempertaruhkan nyawa, dan mengikuti petuah ulamanya. Atau dalam ajaran pada umat Muslim sebagai sosok yang Sami'na Wa Atho'na.

Kultur yang dibangun antara ulama itulah akhirnya tidak sedikit dimanfaatkan oleh politisi, tim kampanye bahkan ulama itu sendiri untuk meraup suara di roda perpolitikan praktis.

Bahkan sejarah tentang perpolitikan Indonesia yang di dalamnya hadir ulama dengan santri-santrinya sebagai roda penggerak massa serta sebagai elite bukanlah sesuatu yang baru. Terpilihnya KH Abdurrahman Wahid (Gus Dur) sebagai Presiden Ke-4 Indonesia menjadikan wajah ulama serta santri sebagai salah satu yang diperhitungkan untuk memimpin wilayah di daerah bahkan nasional. Dimana sebelumnya mayoritas wilayah di Indonesia dipimpin oleh aparat keamanan, pengusaha atau tokoh politik di dalam perpolitikan di daerah hingga Nasional. Selain itu, hadirnya tokoh politik dari Nahdlatul Ulama (NU), Muhammadiyah bahkan 
organisasi massa keislaman lainnya juga menjadi deretan panjang sejarah tokoh agama dan santri berada di dalam perpolitikan Indonesia (Mulkhan, 2009).

Maka, tidak heran jika tokoh agama juga sering dijadikan meme sebagai salah satu daya tarik pemilih agar memilih calon yang mereka usung. Dengan contoh tampilan kedua gambar tokoh di atas, menjadi fenomena yang biasa bahwa nama atau sosok dari tokoh-tokoh dapat "dijual" sebagai salah satu penarik antusias masyarakat dalam pemilihan di salah satu wilayah. Fenomena menghadirkan "sosok" di dalam meme pun tidak hanya menghadirkan tokoh saja, melainkan ada deretan artis serta olahragawan.

3. Artis: Meraup Suara dari Tempelan-tempelan Idola
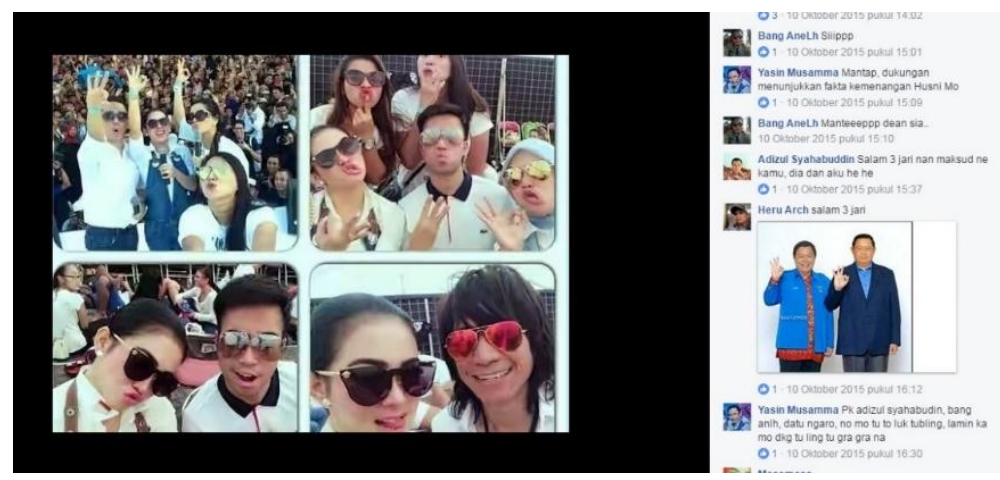

Gambar 5

(Meme artis pada pemilihan Bupati dan Wakil Bupati Kabupaten Sumbawa tahun 2015)

Pada gambar pertama, tim sukses HusniMo memasang foto pasangan Vidi Aldiano, Syahrini dan Abdee Slank. Mereka bertiga merupakan penyanyi dan pemain musik yang terhitung memiliki fans yang banyak. Daya tarik itulah yang akhirnya dimanfaatkan oleh tim kemenangan salah satu calon. Padahal mereka (Aldiano, Syahrini dan Abdee Slank) tidak dengan sengaja mendukung Husni-Mo. Bahkan mereka tidak tahu menahu tentang dirinya yang menjadi salah satu model pada media kampanye meme. Namun, foto dengan momen menunjukkan pilihan nomor urut 3 dengan acungan jari 3 sengaja dihubungkan dengan pilihan kepada Husni-Mo.

Sama seperti yang ditunjukkan oleh tim kampanye Saad-Jaya nomor urut 2 dengan menghadirkan artis sekaligus penyanyi Aura Kasih. Aura Kasih yang memegang foto Saat-
Layaknya ulama yang memiliki banyak santri, artis di dunia hiburan juga memiliki banyak massa, yaitu fans. Kehadiran artis di layar kaca Indonesia menarik daya minat masyarakat untuk mengagumi mereka. Berbicara tentang fans, sulit untuk mendefinisikan secara pendekatan kultural atau politik sehingga seseorang mengagumi sosok orang di luar dirinya. Fans tidak hanya sekedar bahagia dalam membicarakan artis kesukaannya saja, kadangkala juga ada yang terobsesi menjadi diri sang artis (Stokes, 2007:30). Daya tarik itulah menjadi salah satu alasan hadir beragam meme yang menampilkan sosok yang tampan, cantik dan seksi. Alasannya tentu untuk meraup suara dari tempelantempelan foto-foto para idolanya.
Jaya dan rekannya mengacungkan jari menunjukkan peace (dua jari) tersebut tanpa sengaja berpose seperti itu.

Fenomena mengacungkan dua jari bukanlah sesuatu yang susah untuk didapatkan di Internet. Mengacungkan dua jari merupakan sesuatu yang familiar di lakukan oleh beberapa orang.

Siapapun pun calon pada pemilihan eksekutif maupun legislatif dengan nomor urut dua terbilang cukup beruntung. Dua jari yang diacungkan memiliki multi tafsir. Dua jari diacungkan juga dapat diartikan dengan penanda Peace atau dalam dalam konteks di Indonesia disebut sebagai "damai". Terlebih gaya peace, juga menjadi salah satu gaya berfoto di beberapa Negara termasuk Indonesia. Maka tidak heran jika artis dengan gaya peace sering diedit kemudian digabungkan menjadi sebuah meme untuk mendukung salah satu calon dalam pemilihan eksekutif maupun legislatif. 
Penggunaan foto artis sebagai model bukanlah tanpa sebab, keuntungan karena difasilitasi oleh media menjadikan mereka mudah masuk di semua kalangan. Bahkan trend artis menjadi politisi pun kian marak terjadi. Selain karena artis memiliki popularitas yang kuat, memiliki fans serta daya tarik rupawan yang memikat pemilih, tidak sedikit politisi kini sudah mulai hilang kepercayaan di mata pemilih. Terlebih kasus-kasus korupsi, penyalahgunaan wewenang sering dimunculkan oleh media yang dilakukan oleh politisi. Fenomena tersebut akhirnya menguntungkan sosok-sosok di luar politisi. Terlebih demokrasi bukan lagi dikaitkan dengan kapabilitas, melainkan popularitas di tengah masyarakat luas (Wasesa, 2011:16)

Di Indonesia, keterhubungan antara artis dengan politisi atau politisi dengan artis sangatlah dekat. Dalam konteks pop culture muncul salah satu fenomena Idolisasi. Fenomena ini melahirkan banyak artis-artis yang hadir melalui sms. Ajang pencarian bakat dengan polling melalui sms membuat kehadiran artis dadakan memenuhi layar kaca di
Indonesia. Artis seperti inilah kadangkala tidak bertahan lama di dunia layar kaya. Begitu pula dengan politisi karbitan dalam pandangan Idolisasi, dengan memasang baliho dan iklaniklan mereka bisa menjadi artis di ajang pemilihan legislatif maupun eksekutif. Sehingga tidak hanya kapabilitas, popularitas pun kadang hanyalah karbitan (Mahyudin, 2009:149).

Dari fenomena-fenomena yang diuntungkan itulah akhirnya artis dapat mendulang suara pemilih, tidak hanya pada saat fotonya dicatut menjadi sebuah meme saja, melainkan jika dia turun kelapangan untuk menjadi politisi.

4. Olahragawan: Fans Punya Selera

Tidak hanya memukau di arenanya, olahragawan juga terlihat memukau saat berada di meme untuk dijadikan media kampanye oleh beberapa tim kemenangan pada pemilihan legislatif maupun eksekutif. Seperti yang ditampilkan pada media kampanye politik pada calon bupati nomor urut dua di pemilukada Kabupaten Sumbawa tahun 2015 lalu.

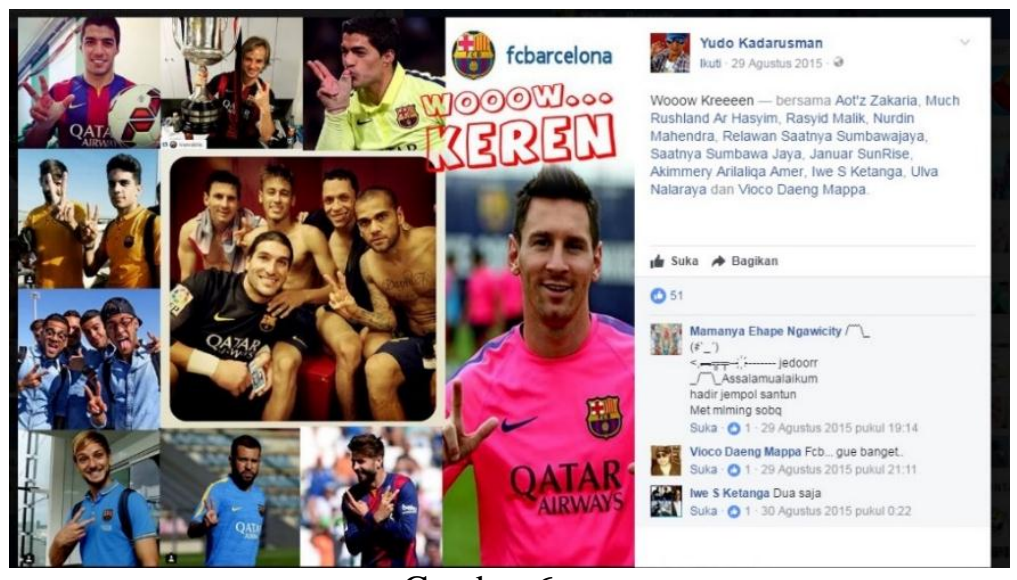

Gambar 6

(Meme olahragawan pada pemilihan Bupati dan Wakil Kabupaten Sumbawa tahun 2015)

Pada kolom komentar, salah satu pendukung ada yang mengucapkan "dua saja",

seraya menunjukkan bahwa gambar tim Barcelona khusus mendukung pasangan nomor urut 2 di pemilukada Bupati dan Wakil Bupati Kabupaten Sumbawa tahun 2015. Walaupun seperti pada contoh meme yang menampilkan artis, tim Barcelona tidak dengan sengaja mendukung pasangan tersebut. Bahkan mereka tidak tahu menahu tentang dirinya yang menjadi salah satu model pada media kampanye meme. Namun, daya tarik yang dihadirkan oleh pemain bola Internasional dijadikan bahan pancingan bagi pemilih. Alasannya karena olahraga seperti bola merupakan salah satu olahraga yang dicintai oleh masyarakat Indonesia. Tidak hanya pemain bola, pada gambar di atas, olahragawan seperti pembalap motoGP yang tidak sengaja menunjukkan jarinya dengan tanda peace juga dicatut, dan dikait-kaitkan dengan pemilukada tersebut. 

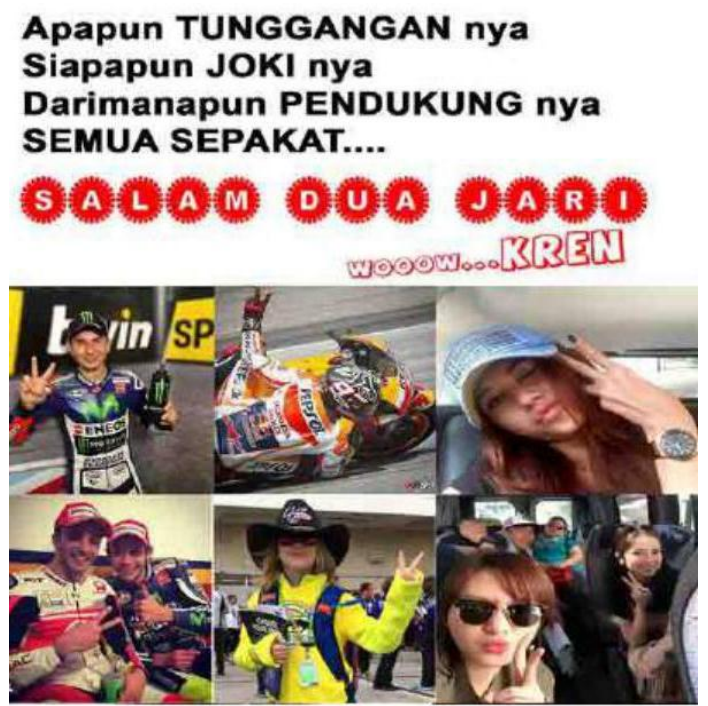

Gambar 7

(Meme olahragawan pada pemilihan Bupati dan Wakil Kabupaten Sumbawa tahun 2015)

Olahraga dan politik memang sesuatu yang jauh keterkaitannya secara ruang lingkup kegiatannya, namun secara kultural keduanya sangatlah dekat. Pada piala dunia tahun 1990 Maradona diangkat oleh Presiden Carlos Menem sebagai duta resmi Argentina, secara tidak langsung hubungan antara Politik dan Olahraga dihubungkan melalui jasa-jasa olahragawan yang mengharumkan nama negaranya. Negara dikaitkan dengan roda pemerintahan yang didapatkan melalui jalur politik; Sama juga seperti yang diungkapkan oleh Hitler bahwa orang besar dapat dianalogikan sebagai pelari marathon di dalam sejarah; Berbeda bagi Mussolini, dalam beberapa pandangannya dia ingin dirinya ditampilkan sebagai pose-pose olahraga seperti sedang main anggar, tenis atau naik kuda saat menghadapi lawan politiknya; sedangkan pada kaum sosialis, olahragawan dapat dianalogikan sebagai robot-robot yang kuat dan tidak kenal lelah, dalam artian semangat ideal kolektivisme yang rasional dan higienis dalam membela Negara (Sugiharto dan Rachmat, 2000:232). Dalam kasus-kasus di atas menunjukkan bahwa hubungan antara politik dan olahraga sangatlah dekat. Terutama jika olahraga dijadikan sebagai alat-alat penguasa sebagai bentuk pencitraan dan keuntungan elite politik praktis. Olahraga menjadi sebuah alat citra yang dikait-kaitkan ke politik. Dengan maksud untuk menjaring suara-suara rakyat yang juga sangat dekat dengan aktivitas olahraga serta olahragawannya.
Meme politik pada penjelasan di atas adalah sebuah korelasi antara budaya di tengah masyakat yang dikaitkan dengan isu-isu yang sedang berkembang. Bentuknya berupa gambar, tulisan maupun citra seseorang. Ditujukan sebagai salah satu alat untuk merubah citra seseorang atau kelompok di luar sosok atau tulisan di dalam meme tersebut. Misalnya seperti penjelasan di atas, sosok artis, tokoh masyarakat, tokoh agama, artis maupun olahragawan dikaitkan-kaitkan dengan sosok calon Bupati dan Wakil Bupati Sumbawa. Padahal, antara materi di dalam meme dengan para calon tidak ada hubungan apapun, bahkan tidak saling mengenal. Namun ada isu maupun budaya yang sama sehingga dikaitkan-kaitkan. Tujuannya, semata-mata untuk keuntungan politik belaka.

Di dalam praktik berpolitik di Indonesia pada masa kini, akhirnya meme dimanfaatkan untuk meraup suara pemilih. Walaupun tim kampanye masing-masing calon sering mengabaikan konteks dan isi dari meme tersebut, sehingga tidak jarang terjadi perdebatan atau pertengkaran di dalam dunia maya.

\section{Ketidakkonsistensi Model Meme}

Pada penggunaan medsos, netizen tidak akan dapat menghindari perdebatan, bahan adu domba atau black campaign yang terjadi. Alasannya, karena demokrasi di dalam dunia maya sangatlah bebas, tidak terkontrol dan berwajah banyak.

Selain karena alasan di atas, perdebatan juga terjadi karena hadirnya subyek-subyek yang memiliki cara pandang berbeda dan memiliki posisi-posisi berbeda. Selain itu, pada fenomena tersebut hadir posisi dominan dan subordinat.

Perbedaan posisi yang terjadi di medsos tidak mengurungkan niat netizen untuk mengomentari status atau postingan yang berbeda dengan posisi mereka. Alasannya, karena komunikasi pada dunia maya juga menekankan pada kebebasan dalam memberikan komentar. Dimana kebebasan tidak hanya dimiliki oleh komunikator saja, melainkan juga dapat dilakukan oleh posisi komunikan.

Perkembangan Internet seperti saat ini menghilangkan ketakutan-ketakutan subyek untuk memberikan komentar. Siapapun dapat berbicara tanpa takut harus bertanggung jawab atas apa yang telah mereka sampaikan. Selain itu, siapapun dapat membuat identitas ganda di media sosial dan dapat menyebarkan berita apapun ke seluruh netizen. 
Pada salah satu postingan di bawah ini, pendukung salah satu calon tidak menerima bahwa tokoh partainya dicatut di dalam meme kampanye politik nomor urut 1. Padahal tokoh di dalam meme tersebut tidak mendukung partai yang mengusung nomor 1. Namun, dengan alasan meraup suara pemilih, pencatutan tersebut tetap diposting oleh tim kampanye atau simpatisan nomor urut 1 .

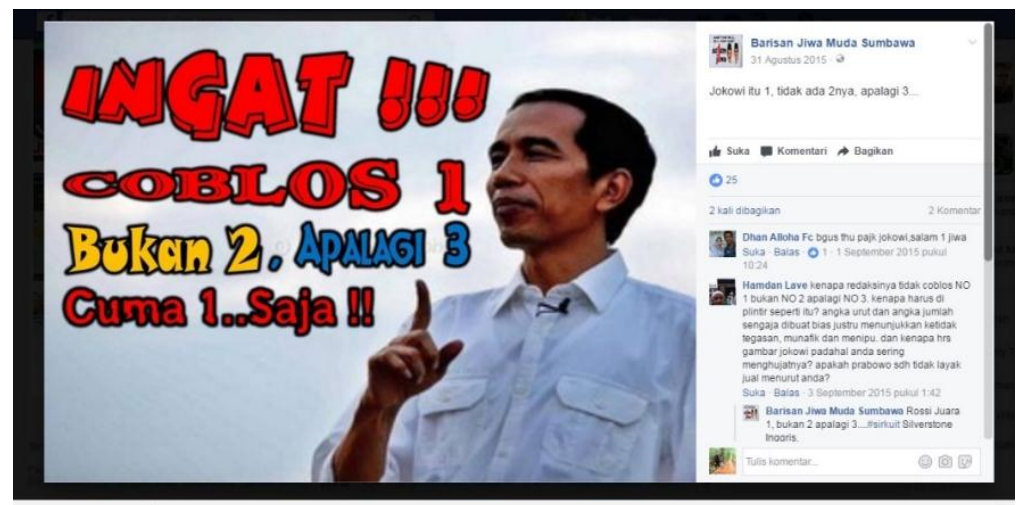

(Pencatutan Jokowi sebagai model meme pasangan nomor urut 1)

Pada kolom kedua netizen memberikan komentar dan kritikan terhadap redaksi dan penggunaan tokoh Presiden Jokowi sebagai model dalam meme tersebut. Terlebih pengupload foto memberikan caption, "Jokowi itu 1, tidak ada 2nya, apalagi 3". Seakan-akan Jokowi memberikan dukungan pada pasangan nomor urut 1 (Jack Morsa-Iwan) yang diusung oleh Partai Keadilan Sejahtera dan Gerindra.

"kenapa redaksinya tidak coblos No. 1, bukan No. 2 apalagi No. 3. Kenapa harus diplintir seperti itu? angka urut dan angka jumlah sengaja dibuat bias, justru itu menunjukkan ketidaktegasan, munafik dan menipu. Dan kenapa harus gambar Jokowi padahal anda sering menghujatnya? Apakah Prabowo sudah tidak layak jual menurut anda ?".

Komentar di atas mengkritisi ketidaktegasan tim kemenangan nomor urut 1 yang didukung oleh PKS dan Gerindra. Dia mempermasalahkan mengapa penggunaan dukungan tidak langsung oleh partai tersebut sedangkan Jokowi merupakan partai dukungan Partai Demokrasi Indonesai-Perjuangan (PDIP) yang pada pemilukada tahun 2015 lalu di Sumbawa mendukung pasangan nomor urut 3.

Tanggapan ini tidaklah datang tanpa sebab, namun ada isu yang melatarbelakangi munculnya perdebatan tersebut. Pada
Gambar 8

pemilihan Presiden dan Wakil Presiden Republik Indonesia tahun 2014 lalu, ada dua nama yang selalu diperbincangkan dan membentuk dua kubu di Indonesia. Kubu PKS dan Gerindra yang pada pilpres sebelumnya mendukung Prabowo Subianto untuk menjadi Presiden pada pemilihan tahun 2014 lalu, sedangkan PDI-P mendukung Jokowi yang kini telah menjadi Presiden (news.detik.com/berita/2580812/ adu-kuatkoalisi-pendukung-jokowi-dan-prabowo) . Dari perdebatan tersebut dapat diambil kesimpulan bahwa adanya isu yang melenceng dari faktanya, kemudian dengan segala cara meme ingin mencoba mencairkan isu dengan mencatut gambar yang tidak sesuai. Namun, di dalam meme tidaklah ada etika khusus untuk membahas permasalahan ini semua. Selain karena kebebasan kreativitas, meme yang sudah di jelaskan pada awal pembahasan adalah salah satu alat yang unik, humor dan lelucon. Terutama jika dikaitkan dengan materi kampanye politik, sehingga pencatutan tersebut masih sesuatu yang lumrah.

Masih di dalam perdebatan pada salah satu media kampanye politik pemilihan Bupati dan Wakil Bupati Sumbawa tahun 2015. Kini foto Prabowo Subianto yang dengan sengaja dicatut pada kolom komentar meme pengusung partai nomor urut 2. Padahal dengan sangat jelas secara kepartaian, Prabowo Subianto mendukung pasangan colon nomor urut 1. 


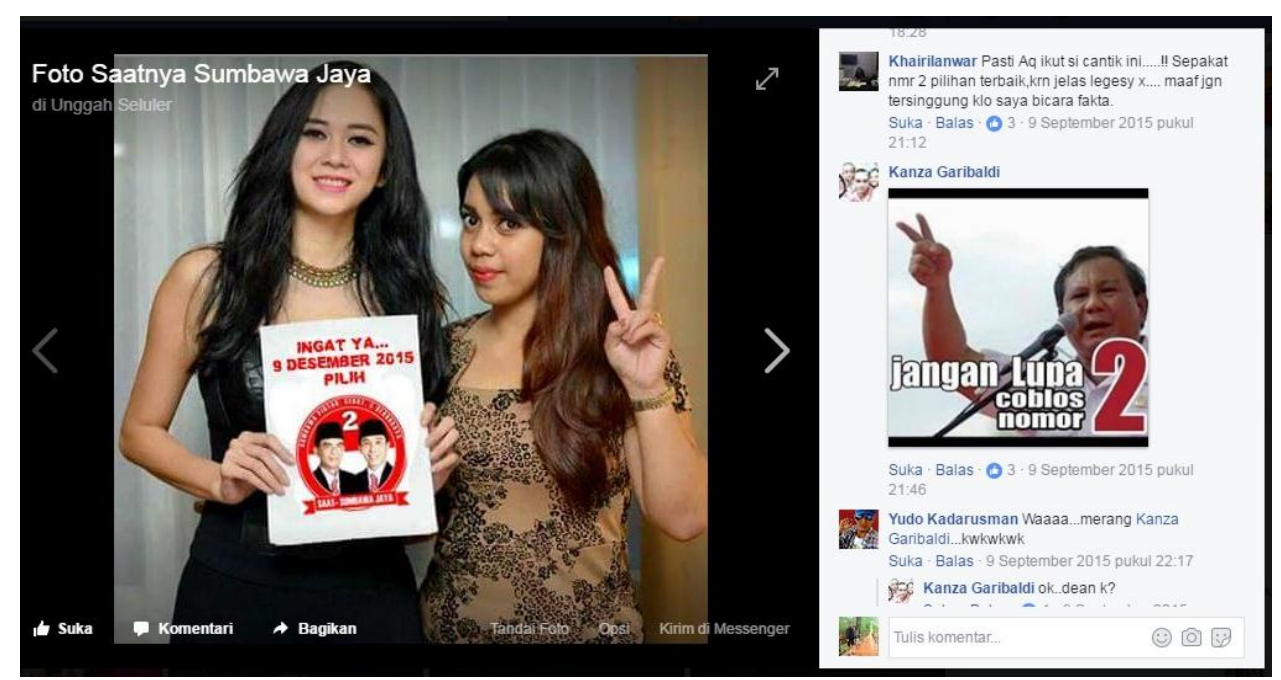

Gambar 8 
(Pencatutan Prabowo sebagai model meme pasangan nomor urut 2)

Sama dengan meme pada nomor urut dua kali ini. Padahal pasangan nomor urut 2 didukung oleh partai Hanura, Nasdem dan PKPI, bukanlah partai Gerindra yang dipimpin oleh Prabowo. Namun mereka memanfaatkan momen dimana Prabowo berpidato, dan dengan secara tidak sengaja mengacungkan 2 jari, seakan-akan memilih nomor dua. Padahal bisa saja dua jari yang dia acungkan dilakukan secara tidak sengaja. Atau bias jadi pada kampanye di lokasi yang lain, namun memilih nomor urut dua yang didukung oleh Gerindra.

Terlebih seperti pada penjelasan di atas, bahwa nomor urut dua terbilang cukup beruntung. Dua jari yang diacungkan memiliki multi tafsir. Dua jari diacungkan juga dapat diartikan dengan penanda Peace atau dalam konteks di Indonesia disebut sebagai "damai". Terlebih gaya peace, juga menjadi salah satu gaya berfoto di beberapa Negara termasuk Indonesia. Begitu juga yang ditampilkan pada foto Prabowo Subianto yang sedang mengacungkan dua jari.

Pada kedua gambar meme di atas bermaksud untuk memanfaatkan momen, dimana Presiden Jokowi atau Prabowo pun mendukung pasangan yang bukan dari partau yang mereka dukung. Seakan-akan ingin berbicara, bahwa calon yang saat ini maju dengan partai pendukungnya, tokohnya saja tidak satu suara dengan partainya. Dengan tujuan ingin merusak suara pemilih pasif. Fenomena ini disebut sebagai ketidakonsistensi pendukung dalam melihat dukungan partai dan tokoh, Model kampanye ini disebut sebagap pragmatis dalam memilih materi kampanye politik, atau memanfaatkan apapun demi keuntungan dan harapan kemenangan semata.

Ada berbagai bentuk materi dalam kampanye politik dengan memanfaatkan meme. Namun semuanya tidaklah bebas dari penilaian netizen, yang di dalam pembahasan ini penulis juga melihat tanggapan khalayak. Apakah mereka pasif, dengan aktif mengkritisi media yang ada. Di dalam tulisan ini juga penulis mengungkapkan bagaimana penerimaan dan respon khalayak terhadap kampanye politik menggunakan meme yang disebarkan oleh tim kampanye masing-masing calon.

\section{Pemilih Muda di tengah-tengah Kampanye Unik}

Sebagai salah satu pemilih pemula, pemilih muda yang baru saja dapat melaksanakan pemilihan umum memiliki beragam pertimbangan dalam memilih calon pemimpin yang akan berkuasa di wiliayahnya. Pilihan-pilihan tersebut dapat disebabkan oleh latar belakang keluarga, latar belakang pendidikan, organisasi, bahkan tidak sedikit yang sudah terjun langsung ke dalam lingkaran partai atau dijadikan sebagai roda penggerak bagi salah satu calon, legislatif maupun eksekutif.

Dari berbagai latar itulah akhirnya meragamkan respon pemilih muda terhadap media kampanye politik berupa meme yang hadir di tengah-tengah.

1. Proximity: Antara Kandidat dengan Pemilih Muda

Kedekatan antara calon eksekutif maupun legislatif dengan pemilihnya merupakan salah satu cara untuk menarik perhatian pemilih, terutama bagi pemilih muda. Dalam dunia politik, kedekatan (proximity) merupakan salah satu daya tarik pemilih bagi kontestan pemilu. Dalam model ini pemilih akan memberikan suaranya kepada partai dan kontestan yang memiliki ketertarikan, nilai dan keyakinan yang sama (Downs dalam Firmanzah, 2006).

Namun realitanya, kadangkala sebagai salah satu pemilik suara di pemilihan umum, pemilih muda selalu dipandang sebelah mata, terlebih bagi pemilih yang baru saja mengikuti pemilihan umum. Padahal pemilih muda juga merupakan salah satu penentu menangnya salah satu calon, dikarenakan jumlahnya yang tidak bisa dianggap sedikit.

Kedekatan serta pemilihan ide-ide kreatif dalam kampanye politik inilah akhirnya dapat menarik perhatian mereka. Terlebih jika ide kreatif tersebut dimanfaatkan melalui media sosial, yang disebut-sebut sebagai dunia anak muda. Seperti yang dijelaskan oleh Drew (2013) bahwa kehadiran media sosial di dalam Internet menghadirkan kehidupan baru bagi masyarakat, yang di dalamnya hadir beragam netizen. Salah satu mayoritas netizen adalah dari kalangan anak muda. 
Kampanye politik melalui medsos inilah akhirnya dianggap sebagai salah satu daya tarik bagi anak muda. Terlebih jika dikaitkan dengan kampanye politik melalui meme. Dimana meme tidak hanya berisi konten yang serius mengenai politik saja, melainkan juga unik, humor dan kreatif.

Jika di dalam kehidupan nyata kedekatan dapat berupa keluarga, kerabat atau rekan. Di dunia maya kedekatan dapat dibentuk oleh kontestan yang mampu bersahabat dengan netizen. Terlebih bagi pimpinan daerah, partai atau kontestan yang memberikan ruang untuk berdiskusi dengan netizen.

Apalagi jika calon kepala daerah dapat mengemas media kampanyenya menjadi lebih kreatif dengan menampilkan visual menarik dan pesan-pesan yang menarik hati anak muda. Misalkan, anak muda lebih familiar dengan musisi, anak muda lebih familiar dengan olahragawan dan anak muda lebih familiar dengan artis-artis. Maka tidak heran jika sosok-sosok seperti itulah yang kadangkala dihadirkan di dalam media kampanye. Salah satu contohnya meme yang beredar di pemiliahn Bupati dan Wakil Bupati Kabupaten Sumbawa tahun 2015.

Selain konten kreatif berupa sosok artis, olahragawan maupun tokoh dimunculkan, penggunaan meme sebagai media kampanye politik juga dapat berupa konten berbahasa daerah. Bahasa menjadi salah satu bentuk ciri-ciri kedaerahan yang jika dikaitkan bagi calon atau kontestan pemilu sebagai sosok pemimpin yang "merakyat" atau dekat dengan rakyat, memahami situasi daerah dan bentuk citra sebagai putra-putri asli daerah.

Terlebih dalam konteks pemilukada di Kabupatan Sumbawa. Sumbawa, oleh Informan dinilai sebagai salah satu daerah diluar "Pusat Kota di Indonesia" (Jakarta dan Pulau Jawa), sehingga tokoh yang menekankan kedaerahan menjadi daya tarik bagi anak muda. Dalam artian calon pemimpin tersebut berasal dari putri-putri asli daerah dan memiliki kedekatan dengan pemilihnya. Namun, tetap kekinian dengan memanfaatkan media sosial sebagai salah satu alat kampanyenya.

\section{Ketenaran versus Ide dan Gagasan}

Kehadiran artis, tokoh dan olahragawan di dalam meme sebagai salah satu media kampanye politik di Pemilukada Kabupaten Sumbawa tahun 2015 menjadi salah satu daya tarik bagi pemilih muda. Terlebih anak muda terasa terwakilkan dengan kehadiran model di dalam meme tersebut.

Misalkan kehadiran tokoh agama seperti Ustad Muhammad Arifin Ilham dapat menjadi daya tarik bagi remaja masjid di Kampus. Terlebih anak muda di Sumbawa meyakini bahwa Kabupaten Sumbawa berada dalam kawasan Nusa Tenggara Barat yang merupakan salah satu wilayah mayoritas tempat berkembangnya umat muslim. Salah satu contohnya ketika Provinsi Nusa Tenggara Barat mengembangkan destinasi wisata halal di tiap-tiap daerahnya (Arzak, 2015:95). Secara tidak langsung Provinsi Nusa Tenggara Barat ingin mencitrakan dirinya sebagai salah satu pusat perkembangan dan wisata muslim di Indoensia. Sehingga mereka merasa terwakili dengan adanya sosok ustad di dalam meme.

Selain sosok Ustad, ada juga Iwan Fals yang hadir sebagai model di salah satu meme pasangan calon bupati Kabupaten Sumbawa. Walaupun aliran musik Iwan Fals tidak mewakili seluruh genre musik, namun sosok Iwan Fals dapat menjadi magnet bagi musisi-musisi dari anak muda. Musisi legendaris yang hampir hadir di seluruh jaman ini dapat mewakilkan ketertarikan musik yang dihubung-hubungkan dengan politik. Tidak terkecuali kehadiran artis, penulis melihat bahwa pemilih muda akan memunculkan daya tarik tersendiri terhadap artis yang dia cintai. Terlebih artis wanita seksi dianggap sebagai salah satu daya tarik bagi anak muda pria dan artis pria tampan sebagai salah satu daya tarik pemilih muda wanita.

Seperti juga Olahraga dapat menjadi sebuah alat yang "empuk" bagi kampanye politik di meme. Dikarenakan olahraga dapat masuk ke semua ranah. Bahkan pemilihan Sepak Bola dan MotoGP yang dihadirkan pada meme pemilukada di Kabupaten Sumbawa tahun 2015 ini juga beralasan. Pertandingan sepak bola dan MotoGP dapat membius penonton disegala kalangan, terlebih euphoria olahraga tersebut akan terus berlanjut jika disaksikan secara bersamaan atau "nobar, nonton bareng".

Bahkan dari hasil wawancara kepada salah satu informan, pertandingan bola dan MotoGP akan membius para penonron, hingga tidak memperdulikan kegiatan yang ada disekitarnya. Fenomena tersebut menunjukkan besarnya antusias anak muda dengan tontonan olahraga seperti Sepak Bola dan MotoGP. Ketertarikan inilah akhirnya dimanfaatkan oleh kandidat calon pemimpin daerah untuk dimunculkan di dalam pesan meme. 
Namun, di dalam dunia olahraga ada fans ada ada juga musuh. Salah satu respon Informan menjelaskan bahwa kehadiran salah satu olahragawan atau tim dapat menjadi sebuah kekurang pula. Misalnya saja pada saat foto tim Barcelona yang sekaan-akan mendukung salah satu calon pemilukada, akan berpengaruh bagi fans Real Madrid. Beberapa informan akan merasa tidak suka dengan tampilan meme tersebut. Ketidaksukaan tersebut dapat berdampak bagi hilangnya citra positif tentang calon yang menampilkan salah satu tim saja. Maka, dengan alasan tersebut para calon dapat menghadirkan meme dengan beragam tim olahraga.

Dari berbagai fenomena "orang terkenal" yang dihadirkan sebagai model dalam meme tersebut akhirnya menghilangkan kehadiran kemampuan, visi dan misi serta tampilan sebenarnya pada calon kepala daerah. Ini bukanlah sesuatu yang hadir begitu saja, Indonesia dengan sejarahnya selalu menghadirkan tokoh di dalam kepemimpinan atau sosok.

Di tengah kampanye politik, pemilih lebih menyukai sosok dibandingkan calon yang mengumbar visimisi. Pemilih akan lebih menyenangi personal branding dibandingkan marketing partai atau citra yang dibuat-buat (Tristanto, 2013:121) Misalkan Soekarno yang selalu diidam-idamkan oleh hampir seluruh masyarakat Indonesia. Soekarno hadir sebagai pahlawan bagi Indonesia di tengah jajahan bangsa Asing, sehingga wacana ketokohan seringkali menang dibandingkan visi misi. Selain itu, Tentang ketokohan Soekarno seringkali dikaitkan-kaitkan dengan kepemimpinan kader Partai Demokrasi Indonesia (PDI P), maka tidak heran ketika pelaksanaan acara resmi PDI P, panitia selalu memasang gambar Soekarno sebagai latar panggungnya. Tujuannya untuk mengaitkan antara kader PDI-P dengan kepemimpinan serta ketokohan Soekarno. Atau dapat disebut sebagai wacana rasionalitas tentang kemampuan seseorang akan kalah dengan wacana figur atau symbol yang dihidupkan di dalam masyarakat.

3. "Kekinian yang Merakyat": Sosok yang dirindukan Pemilih Muda

Selain kehadiran tokoh di tengah masyarakat, kehadiran pimpinan partai dan kader partai juga menjadi daya tarik pemilih muda. Terlebih pimpinan atau kader yang dekat dengan rakyat dan dapat menguasai teknologi informasi untuk menjangkau mereka.

Contohnya kehadiran Jokowi dan Prabowo di salah satu meme dan kolom komentar pasangan calon Bupati dan Wakil Bupati Kabupaten Sumbawa. Selain karena nuansa pertarungan Pemilihan Presiden tahun 2014 lalu masih berasa dan dikaitkan-kaitkan di sejumlah pemilukada. Kehadiran kedua tokoh tersebut juga cukup berbeda dengan beberapa pimpinan partai dan kader partai lainnya.

Prabowo Subianto yang selalu kekinian jika berhubungan dengan media sosial, menjadi salah satu tokoh partai yang merespon masyarakat dengan sangat cepat melalui media faecbook dan twitternya. Terlebih Gerindra yang juga kendaraan partai Prabowo merupakan salah satu partai yang masif menggunakan media sosial untuk menarik suara anak muda. Bahkan, salah satu hasil survey pemilihmuda.com menyatakan bahwa Gerindra adalah partainya anak muda (http://www.sayangi.com/2014/03/14/19846/news/survei-gerindra-partai-pilihan-anak-muda diakses pada 13 Juli 2017)

Selain kekinian, Prabowo juga dicitrakan sebagai pemimpin yang merakyat, citra tersebut dibentuk melalui kepengurusannya sebagai Ketua Himpunan Kerukunan Tani Indonesia. Terlihat pada pemberitaan media menjelang pilres tahun 2014, Prabowo dicitrakan sebagai ketua kaum tani dan mendapatkan dukungan dari asosiasi dagang se-Indonesia. Citra tersebut menegaskan bahwa dirinya dan Gerindra sebagai partainya rakyat (Firmanzah, 2010:499). Tidak heran respon informan terhadap munculnya Prabowo di dalam meme yang mendukung non partainya pun di sambut baik oleh informan.

Begitu pula dengan Jokowi, aktor politik yang terbilang sering menggunakan media sosial untuk menyapa rakyatnya ini sangat familiar di wajah subscriber youtube. Selain sebagai strategi politik untuk membentuk citra positif, cara ini juga mampu menjangkau beberapa masyarakat yang berada jauh dari Jakarta atau tempat dia bekerja sebagai presiden. Jokowi pun sering memanfaatkan youtube dengan akunnya Presiden Joko Widodo, Jokowi dalam program kerjanya ke daerah-daerah kadangkala membuat vlog. Tujuanya agar memuncul citra kekinian dan citra merakyat. Dengan memanfaatkan medsos Jokowi 
akan dikenal sebagai pemimpin yang merakyat, terutama bagi anak muda yang sering dilabelkan sebagai kelompok yang tidak terlalu peduli dengan perpolitikan Negara.

Dengan memanfaatkan medsos, Jokowi dapat menyentuh anak muda yang jauh dari politik praktis. Cara ini juga dapat menjadi salah satu peluang untuk meraih suara pemilih muda di pemilihan eksekutif nantinya. Selain itu, untuk aktor elite politik yang sedang memimpin jalannya roda pemerintahan di beberapa wilayah, dapat menjadikan medsos sebagai alat sosialisasi, mengabarkan serta menceritakan program-progarm dan kemajuan yang telah dia lakukan selama ini saat memerintah Indonesia.

Dari citra kekinian dan merakyat yang dibentuk oleh tokoh partai dan tokoh nasional itulah akhirnya dimanfaatkan oleh calon-calon pemimpin di daerah. Pertarungan citra dimanfaatkan oleh kaderkader partai pada saat pemilukada, walaupun kadangkala hadir ketidakkonsistensinan. Seringkali hadir konten meme yang pragmatis. Misalnya Prabowo mendukung calon yang diusung PDI-P atau terlihat meme Jokowi yang mendukung calon dari partai Gerindra. Seperti yang dilakukan oleh simpatisan dan tim kampanye calon Bupati dan Wakil Bupati Kabupaten Sumbawa tahun 2015 yang mencatut foto Jokowi dan Prabowo. Walaupun mereka dengan sengaja mengetahuai sosok kedua tokoh terebut tidak mendukung partai yang diusung calon.

Respon ini dapat berdampak bagi pemilih pasih, bahkan informan menganggap pesan di dalam meme tersebut dapat merubah arah pilihannya, mengikuti sosok yang mendukung salah satu calon.

\section{PENUTUP}

Kesimpulan

Kehadiran meme pada pemilukada di Kabupaten Sumbawa pada tahun 2015 membawa tampilan baru bagi materi kampanye politik. Terlebih jika dikaitkan dengan ketertarikan pemilih muda dalam merespon dan menerima kampanye politik tersebut. Meme hadir untuk memberikan gambaran dan respon-respon terhadap isu politik yang ada di tingkat nasional hingga daerah, selain itu juga tampilan pada meme juga hadir sebagai pembacaan terhadap budaya yang ada di sekitar masyarakat. Maka tidak heran jika proximity, ketokohan yang dilanggengkan di tengah masyarakat dan citra kekinian serta merakyat menjadi salah satu daya tarik bagi pemilih muda. Selain itu, kampanye politik berupa meme tersebut berada di wilayah atau dunia bagi anak muda, yaitu di media sosial. Sehingga kadangkala bukan pemilih muda yang harus menyesuaikan diri pada politik praktis, melainkan sebaliknya. Kampanye politik yang disebarkan melalui media sosial oleh calon-calon eksekutif maupun legislatif lah yang menyesuaikan diri dengan pemilih muda.

\section{Saran}

Di dalam penelitian ini penulis melihat dua sisi kampanye politik pada pemilukada Bupati dan Wakil Bupati Kabupaten Sumbawa tahun 2015, yaitu melalui medianya berupa meme dan melalui khalayaknya atau penikmat meme tersebut. Namun pemilihan dua objek analisis itu menghasilan data yang tidak mendalam. Selain itu, karekteristik media sosial pun tidak banyak dibahas dalam tulisan ini, padahal karakteristik itu berperan untuk menampilkan model pesan yang hadir di tengah netizen. Oleh karena ini perlu ada kajian yang khusus membahas meme sebagai media kampanye politik saja, dan perlu adanya analisis pada media kampanye lainnya seperti pada video youtube_atau pesan-pesan di dalam facebook dan twitter oleh calon legislatif maupun eksekutif yang akan mencalonkan diri.

\section{DAFTAR PUSTAKA}

Arzak, Miftahul, 2015, Wacana Pendidikan bagi Anak di Tabloid Koran Anak, Tesis Magister Kajian Budaya dan Media, Universitas Gadjah Mada.

Barker, Chris, 2011, Cultural Studies, Yogyakarta, Kreasi Wacana.

Brunello, J, 2012, Internet-memes and everyday- creativity: Agency, sociability and the aesthetics of postmodernism. Tesis University of California, Los Angeles, United States of America.

Drew, Jesse, 2013, A Social History of Contemporary Democratic Media, City Light Press, San Francisco. Eriyanto, 2009, Analisis Wacana, Yogyakarta, LKiS.

Firmanzah, 2008, Marketing Politik: Antara Pemahaman dan Realitas, Yayasan Pustaka Obor Indonesia, Jakarta. 
,2010, Persaingan, Legitimasi, Kekuasaan dan Marketing Politik: Pembelajaran Politik Pemilu 2009, Yayasan Pustaka Obor Indonesia, Jakarta.

Hall, Stuart, 2002, Critical Dialogues in Cultural Studies, London, Routledge.

Julmansyah dan Arzak, Miftahul, 2017, Mengantar Pemimpin Baru: Di Balik Pelaksanaan Pilkada Kabupaten Sumbawa 2015, Arti Bumi Intaran, Yogyakarta

Komisi Pemilihan Umum, 2010, Modul Pemilih untuk Pemula, KPU, Jakarta.

Kompas, 2009, The Victory if Yours, PT Kompas Media Nusantara, Jakarta

Mahyudin, M Alfan Alfian, 2009, Menjadi Pemimpin Politik, PT Gramedia Pustaka Utama, Jakarta

Maliki, Imam dan Riri Satria, 2013, Pengaruh Kampanye Politik di Media Sosial terhadap Opini yang Terbentuk:

Studi Kasus Pilkada DKI Jakarta 2012, Dalam Jurnal Informatika dan Komputasi STMIK, Vol 7, No. 1, Hal 41-56.

Morley, David, 1992, Television, Audience and Cultural Studies, London, Routledge

Mulkhan, Abdul Munir, 2009, Politik Santri: Cara Menang Merebut Hati Rakyat, Kanisius, Yogyakarta.

Nurudin, 2013, Media Sosial Baru dan Munculnya Revolusi Proses Komunikasi, Dalam Jurnal Komunikator Vol. 5, No.2, Hal 127-142.

Pamungkas, Cahyo, 2017, Mereka yang Terusir: Studi Tentang Ketahanan Sosial Pengungsi Ahmadiyah dan Syiah di Indonesia, Yayasan Pustakan Obor Indonesia, Jakarta.

Pawito, 2008, Penelitian Komunikasi Kualitatif, Yogyakarta, LKiS

Respati, Wira, 2014, Transformasi Media Massa Menuju Masyarakat Informasi di Indonesia. Dalam Jurnal Humaniora Vol 5, No. 1, Hal 39-51.

Shiraishi, Saya S. (2001). Pahlawan-pahlawan Belia: Keluarga Indonesia di Dalam Politik, Kepustakaan Populer Gramedia, Jakarta

Stokes, Jane, 2007, How to Do Media and Cultural Studies: Panduan untuk Melaksanakan Penelitian dalam Kajian Media dan Budaya, Bentang, Yogyakarta. Diterjemahkan dari How to Do Media and Cultural Studies, Sage, NY.

Storey, John, 2008, Cultural Studies dan Kajian Budaya Pop, Jalasutra, Yogyakarta.

Sugiharto, Bambang dan Rachmat, Agus, 2000, Wajah Baru Etika dan Agama, Kanisius, Yogyakarta.

Susanto, Budi, 2007, Sisi Senyap Politik Bising, Kanisius, Yogyakarta.

Trisnanto, A.M. Adhy, 2013, Ngobrol Santai Soal MarComm, Jogja Bangkit Publisher, Yogyakarta.

Wadipalapa, Rendy Pahrun, 2015, Meme Culture dan Komedi Satire Politik: Kontestasi Pemilihan Presiden dalam Media Baru. Dalam Jurnal Ilmu Komunikasi, Vol 12, No. 1, Hal 1-17.

Wasesa, Agung Silih, 2011, Political Branding \& Public Relation: Saatnya Kampanye Sehat, Hemat dan Bermartabat, PT Gramedia Pustaka Utama, Jakarta.

Winarno, Budi, 2008, Sistem Politik Indonesia Era Reformasi. MedPress, Jakarta. 